\title{
The Inflammatory Process Modulates the Expression and Localization of WT1 in Podocytes Leading to Kidney Damage
}

\author{
MARIELA ARELLANO-RODRÍGUEZ ${ }^{1}$, PABLO ZAPATA-BENAVIDES ${ }^{1}$, \\ NORMA CESILIA ARELLANO-RODRÍGUEZ ${ }^{1}$, JUAN MANUEL IZAGUIRRE-ÁLVAREZ ${ }^{1}$, \\ MOISÉS ARMIDES FRANCO-MOLINA ${ }^{1}$, FELIPE DE JESÚS TORRES DEL MURO ${ }^{1}$, \\ EDGAR MENDOZA-GAMBOA ${ }^{1}$, ADOLFO SOTO-DOMÍNGUEZ ${ }^{2}$, \\ SANTIAGO SAAVEDRA-ALONSO ${ }^{1}$ and CRISTINA RODRÍGUEZ-PADILLA ${ }^{1}$ \\ ${ }^{1}$ Department of Microbiology and Immunology, Faculty of Biological Sciences, \\ Autonomous University of Nuevo Leon, Nuevo León, Mexico; \\ ${ }^{2}$ Department of Histology, Faculty of Medicine, Autonomous University of Nuevo Leon, Nuevo León, Mexico
}

\begin{abstract}
Background/Aim: Wilms' tumor 1 (WT1) is involved in the development of the urogenital system and is expressed in podocytes throughout life. Inflammation of renal glomeruli causes renal damage-induced nephrotic syndrome and steroid-resistant nephrotic syndrome have mutations in the WT1 gene. The aim of this work was to determine if the inflammatory process modulates the expression and localization of WT1 in podocytes that cause kidney damage using lipopolysaccharide (LPS)-treated mice as a sepsis model. Materials and Methods: In investigation of renal damage, proteinuria and histology were analyzed. WTI modulation was analyzed by indirect immunofluorescence, immunohistochemistry and western blot assays, and proinflammatory cytokines were analyzed by quantitative polymerase chain reaction assay. Results: WT1 expression decreased most at 24 and $36 \mathrm{~h}$ after the induction of inflammation and phosphorylated WT1 was mainly localized in the cytoplasm, reduced nephrin mRNA expression and increased mRNA expression of tumor necrosis factor $\alpha$ and interleukin 1 $\beta$. Conclusion: These results indicate that the immune system plays an important role in the modulation of $W T 1$, leading to kidney damage.
\end{abstract}

This article is freely accessible online.

Correspondence to: Dr. Pablo Zapata-Benavides, Department of Microbiology and Immunology, Faculty of Biological Sciences, Autonomous University of Nuevo Leon (UANL), Unit C, Pedro de Alba S/N, San Nicolás de los Garza, Nuevo León, 66450, México. Tel: +52 8183294115, Fax: +52 8183524212, e-mail: pablozapata@hotmail.com; pablo.zapatabn@uanl.edu.mx

Key Words: WT1 phosphorylated, kidney, sepsis, lipopolysaccharide, nephrotic syndrome.
Wilm's tumor-1 gene (WT1) is one of the main genes involved in the survival of podocytes and in efficient renal filtration. Inflammatory processes lead to kidney failure and this might possibly occur through modulation of WT1. WT1 encodes a transcription factor, a zinc finger protein that has four major isoforms by alternative splicing in exon $5(17 \mathrm{AA} \pm)$ and exon 9 (KTS \pm ) (1). The KTS- isoform has higher affinity for DNA, KTS+ co-localizes with spliceosome proteins in the cytoplasm $(2,3)$. WT1 plays a crucial role in embryogenesis, primarily in gonadal and kidney development; in adults its expression is limited to specialized visceral cells in the kidney (podocytes) and is essential for maintenance and modulating several genes, such as, podocalyxin, nephrin (NPHS1), and paired-box transcription factor (4-6). Mutations or reduction of WT1 expression may lead to reduced expression of nephrin and podocalyxin and is associated with nephropathies such as glomerulosclerosis $(5,7-10)$.

Nephrotic syndrome is the most frequent renal syndrome in childhood, its histological classification is: Minimal nephrotic change, focal segmental glomerulosclerosis, and diffuse mesangial sclerosis, and according to its extent of response to steroids is classified as sensitive and resistant nephrotic syndrome (11).

Mutation of WT1 is commonly reported in children with steroid-resistant nephrotic syndrome, a rare disease that affect $10-15 \%$ of patients with nephrotic syndrome $(12,13)$. About $80 \%$ of all children with sporadic nephrotic syndrome respond to steroid treatment, however, no mutations were found in WT1 in a large cohort study (14). Reduction in expression steroid-resistant nephrotic syndrome and to a lesser extent in patients with steroid-sensitive nephrotic syndrome (15). In a murine model of systemic inflammation induced by lipopolysaccharide (LPS), $24 \mathrm{~h}$ after LPS administration, WT1 was translocated to the cytoplasm and was associated with a decrease in the expression of nephrin, a key component for 
maintaining the slit diaphragm in podocytes and essential for correct glomerular filtration, thereby showing WT1 acts as a transcriptional factor for up-regulating nephrin gene (16).

In A459 lung cancer cells treated with tumor necrosis factor alpha $(\mathrm{TNF} \alpha)$, translocation of WT1 protein to cytoplasm has been observed, suggesting that an inflammatory stimulus can alter its intracellular localization and transcriptional function (17).

Phosphorylation may play a role in modulating the transcriptional regulatory activity of WT1 through interference with nuclear translocation, as well as by inhibition of WT1 DNA-binding (18) by cAMP-dependent protein kinase-mediated phosphorylation of Ser-365 and Ser393 in the zinc finger domain (19).

Sepsis is a result of the systemic inflammatory response and is characterized by the release of pro- and antiinflammatory cytokines induced by infection. Acute renal injury is common in critically ill patients in the presence of acute inflammation and has a strong link to the progression of chronic renal damage $(20,21)$.

There is evidence that inflammation plays an important role in damage to various organs, including kidneys (22). In this work, we evaluated the effect of pro-inflammatory cytokines on the modulation of WT1 expression and its translocation to the cytoplasm.

\section{Materials and Methods}

Animal model. Female BALB/c mice (8-10 weeks old) were obtained from Harland Mexico (Mexico City, Mexico). The mice were caged under controlled room temperature, humidity, and light (12/12h lightdark cycle) with water and food ad libitum. LPS of Escherichia coli O111:B4 (Sigma Aldrich, Toluca, Mexico City, Mexico) and a single injection of LPS was administered at a dose of $8 \mathrm{mg} / \mathrm{kg}$ intraperitoneally (16); saline solution was used for control, untreated mice. The mice were sacrificed with an intraperitoneal injection of $200 \mathrm{mg} / \mathrm{kg}$ of sodium pentobarbital solution at 12, 24, 36, 48 and 72 $\mathrm{h}$, with $\mathrm{n}=5$ at each timepoint, and then kidney tissue and blood were collected. The urine was collected before sacrificing the animals.

Two mice for kidney explants were injected with $1 \mathrm{mg} / \mathrm{kg}$ of LPS every 2 days to induce chronic kidney injury as a positive control (21). All experiments were carried out in accordance with prior approval from the Institutional Animal Care and Use Committee of the Faculty of Biological Sciences (CEIBA-2016-034).

Kidney explants. From the kidney of BALB/c mice, tissue slices 250$300 \mu \mathrm{m}$ thick were prepared with a Krumdieck tissue slicer (Alabama Research and Development, Munford, AL, USA) at $4^{\circ} \mathrm{C}$ with constant flow of buffer of Krebs Henseleit bicarbonate (KB) that was aerated with $5 \% \mathrm{CO}_{2}$. The slices were harvested in $\mathrm{KB}$ buffer at $4^{\circ} \mathrm{C}$. Kidney explants were placed in 12-well plates with Dulbecco's modified Eagle's medium/F12 medium supplemented with $10 \%$ fetal bovine serum and $5 \%$ antibiotic-antifungal agent, and incubated at $37^{\circ} \mathrm{C}$, with $5 \% \mathrm{CO}_{2}$ and stirring at $25 \mathrm{rpm}$. The explants were treated with 10 $\mathrm{ng} / \mathrm{ml}$ of TNF $\alpha$ (R \& D Systems, Minneapolis, MN, USA), $20 \mathrm{ng} / \mathrm{ml}$ of interleukin $1 \beta$ (IL1 $\beta$; R \& D Systems) and $100 \mathrm{ng} / \mathrm{ml}$ of LPS and analyzed at 6,12 and $24 \mathrm{~h}$ later.
Urinary protein. Urine samples were collected at each timepoint above. The protein concentration was measured using DC Protein Assay kit (Bio-Rad, Hercules, CA, USA) and albuminuria was evaluated using sodium dodecyl sulfate-polyacrylamide gel electrophoresis and based on the band size of bovine serum albumin (16).

Pro-inflammatory cytokines. Levels of IL6, IL1 $\beta$, and TNF $\alpha$ were measured using sandwich enzyme-linked immunosorbent assay kits (PeproTech, Mexico City, Mexico).

Quantitative polymerase chain reaction $(q P C R)$. Total RNA was isolated from renal tissues using Trizol ${ }^{\mathrm{TM}}$ Reagent (Invitrogen, Carlsbad, CA, USA) according to the manufacturer's instructions. Single-stranded cDNA was synthesized by reverse transcription using High Capacity cDNA Reverse Transcription Kit (Applied Biosystems, Foster City, CA, USA) according to the manufacturer's instructions. Real-time PCR was performed using the 7500 Real-Time PCR System (Applied Biosystems) with TaqMan gene expression assays. Comparative real-time PCR assays were performed for each sample in triplicate. The primers for WT1 were forward: 5-TCTGCGG AGCCCAATACAG-3'; reverse: 5'-CACATCCTGAATGCCTCT GAAGA-3'; and probe FAM: 5-CACCGTGCGTGTGTATT-3' NFQ; the protocol was performed for $95^{\circ} \mathrm{C}$ for $10 \mathrm{~min}$ and 40 cycles at $94^{\circ} \mathrm{C}$ for $30 \mathrm{~s}$ and $64^{\circ} \mathrm{C}$ for $30 \mathrm{~s}$. The relative expression of $W T 1$ gene was calculated using the equation $2^{-\Delta \Delta C T}$ (23) with glyceraldehyde-3phosphate dehydrogenase (GAPDH) gene (Applied Biosystems) being used for normalization.

Expression of nephrin mRNA was determined with $3 \mu \mathrm{g}$ of cDNA and the following primers: Forward: 5'-CCCCAACATCG ACTTCACTT-3' and reverse: 5'-GGCAGGACATCCATGTAGAG-3' at $94^{\circ} \mathrm{C}$ for $30 \mathrm{~s}, 60^{\circ} \mathrm{C}$ for $30 \mathrm{~s}$ and $72^{\circ} \mathrm{C}$ for $30 \mathrm{~s}$ for 30 cycles $(372$ bp) (16). For the expression of $G A P D H$, primers used were: Forward: 5'-ACCACAGTCCATGCCATCAC-3', reverse: 5'-TCCACCACCC TGTTGCTGTA-3', with the following reaction conditions: $94^{\circ} \mathrm{C}$ for $40 \mathrm{~s}, 60^{\circ} \mathrm{C}$ for $30 \mathrm{~s}$ and $72^{\circ} \mathrm{C}$ for $40 \mathrm{~s}$ for 35 cycles (452 bp). Expression of WT1: Forward 5'-CACATGAGAGAAACGCCCCTTCATGTG-3', reverse 5'-TTTGAGCTGGTCTGAACGAGAAA-3' at $94^{\circ} \mathrm{C}$ for $40 \mathrm{~s}$, $64^{\circ} \mathrm{C}$ for $30 \mathrm{~s}$ and $72^{\circ} \mathrm{C}$ for $30 \mathrm{~s}$ for 35 cycles $(160 \mathrm{bp})$. The expression of $W T 1$ isoforms $\mathrm{KTS} \pm$ and $17 \mathrm{AA} \pm(\mathrm{F} 2-\mathrm{R} 2$ primers to detect $17 \mathrm{AA}+/-$ and F3-R3 to detect KTS +/- splicing isoforms) was performed by conventional PCR according to Oji et.al. (24). The determination of the expression of $\beta$-actin was performed according to Laux et al. (25). The products were observed using $10 \%$ polyacrylamide gel electrophoresis for the $\mathrm{KTS} \pm$ isoform and a $2 \%$ agarose gel for the $17 \mathrm{AA} \pm$ isoform.

Immunofluorescence. The kidneys from LPS-treated mice and controls were fixed in $10 \%$ formalin and processed for hematoxylin and eosin staining, immunohistochemistry and immunofluorescence.

To determine the location of WT1 in mice treated with LPS, 4- $\mu$ mthick sections of renal tissue mounted on microscope slides were used. The specimens were dewaxed, permeabilized with Triton X-100 [0.1\% Triton with $1 \%$ sodium citrate in phosphate-buffered saline (PBS)] and washed three times with PBS. The tissues were blocked with $20 \%$ fetal bovine serum in PBS for $30 \mathrm{~min}$ and incubated at $4{ }^{\circ} \mathrm{C}$ overnight with monoclonal antibody to WT1 sc-7585 (F-6) (Santa Cruz Biotechnology, Santa Cruz, CA, USA) diluted 1:100 in 10\% fetal bovine serum in PBS. After washes with PBS, the presence of bound antibody was identified by staining with goat anti-mouse $\mathrm{IgG}$ Texas Red sc-2979 (Santa Cruz Biotechnology). The slides were counterstained with 4',6-diamidino-2-phenylindole. Finally, the slides were mounted and qualitatively examined using an Olympus 

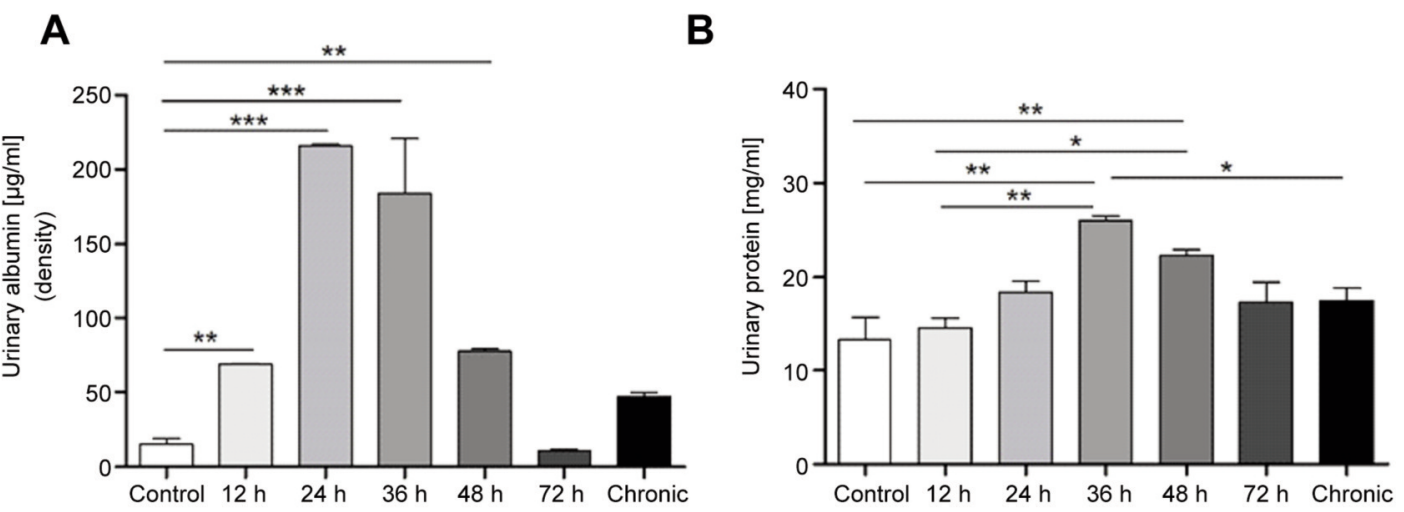

\section{C}
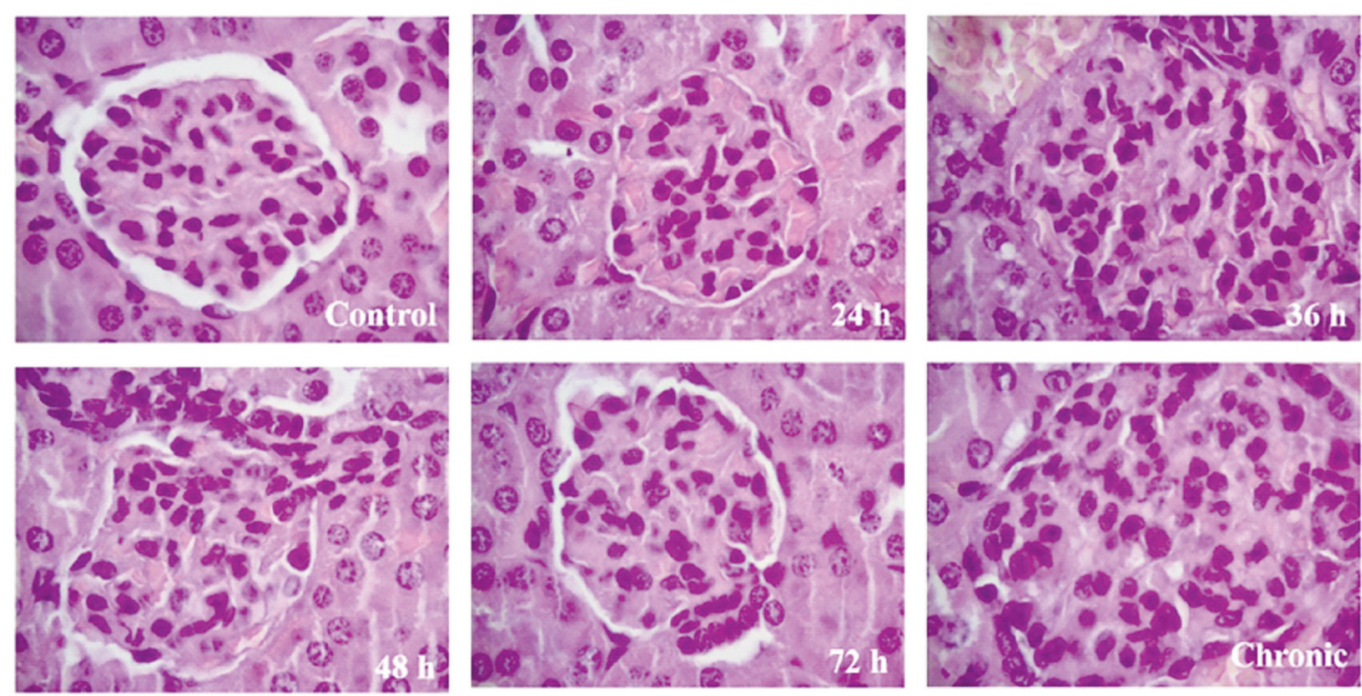

Figure 1. Effect of systemic inflammation on the kidney. Concentrations of urinary albumin (A) and urinary protein (B) as markers of kidney damage in mice treated with lipopolysaccharide. $C:$ A representative image of renal histology of mouse (hematoxylin and eosin staining) at different times $(12,24,36,48$, and 72 h) after lipopolysaccharide injection, with comparison of a model of chronic inflammation, magnification 100x. Significantly different at: $* p \leq 0.05, * * p \leq 0.01$ and $* * * p \leq 0.001$.

BX61W1 confocal microscope with a 40x water immersion objective and Fluoview 4.0a software (Olympus, Tokyo, Japan).

Immunohistochemistry. To determine phosphorylated (p)-WT1 in podocytes from LPS-treated mice, polyclonal antibodies to p-WT1 serine 393, sc-12933 and 363, sc-12934-R (Santa Cruz Biotechnology, Dallas, TX, USA) were used. Slides containing 4- $\mu \mathrm{m}$ sections of renal tissue were dewaxed and permeabilized. Immunohistochemistry was performed using Universal Quick Kit (Vector Laboratories, Burlingame, CA, USA) according to the manufacturer's protocol. The slides were examined using light microscope with a $100 \times$ oil immersion objective (Primo Star, Carl Zeiss, GmbH, Germany).

Western blot. Total protein was isolated with $200 \mu \mathrm{l}$ of lysis buffer (1\% Triton, $150 \mathrm{mM} \mathrm{NaCl}, 25 \mathrm{mM}$ Tris- $\mathrm{HCl} \mathrm{pH} \mathrm{7.6),} \mathrm{and} \mathrm{the}$ concentration was measured using DC Protein Assay kit (Bio-Rad). Protein $(50 \mu \mathrm{g})$ was separated using $12 \%$ sodium dodecyl sulfate polyacrylamide gel electrophoresis and analyzed by western blotting with WT1 [F6] antibody sc-7585 (Santa Cruz Biotechnology). Samples were normalized using anti-GAPDH (AB2302; Sigma, San Louis, MO, USA). Proteins were visualized using a Lumi-Light Western Blotting system sc-2048 (Santa Cruz Biotechnology).

Statistics. Statistical analyses were performed using SPSS 17.0 software (SPSS Inc., Chicago, IL, USA). The results are presented as the mean $\pm \mathrm{SD}$. Comparisons were made using an analysis of variance with tests with Tukey's statistical and considered significant at $p$-value less than or equal to 0.05 .

\section{Results}

Induction of kidney damage in BALB/c mice by LPS. It is well established that podocyte injury is associated with increased proteinuria. Albumin and total protein in urine were determined by sodium dodecyl sulfate-polyacrylamide gel electrophoresis 

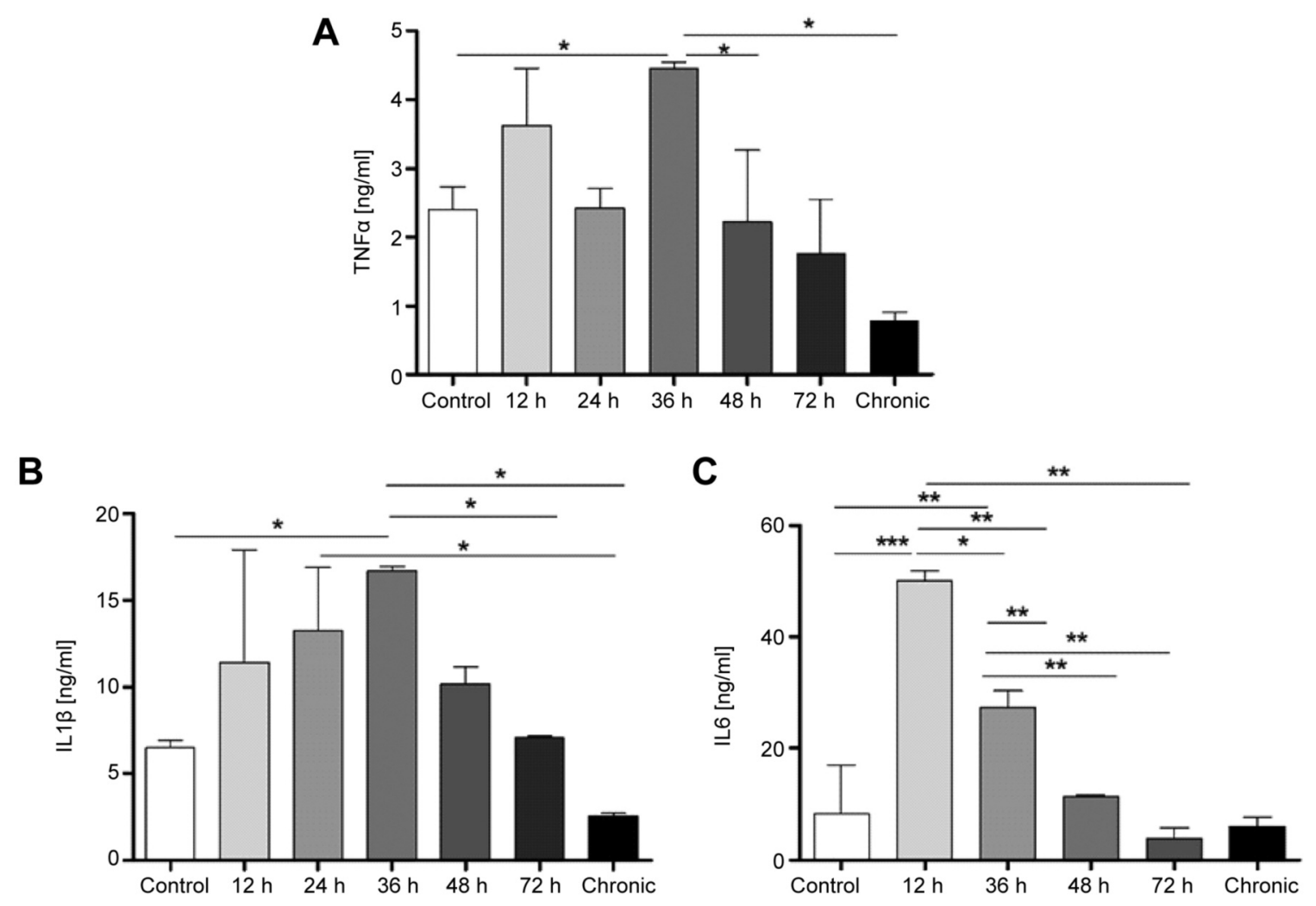

Figure 2. Time course of levels of pro-inflammatory cytokines tumor necrosis factor alpha (TNF $\alpha)(A)$, interleukin $1 \beta(I L 1 \beta)(B)$ and IL6 (C) in serum from mice following intraperitoneal administration of lipopolysaccharide. Significantly different at: $* p \leq 0.05, * * p \leq 0.01$ and $* * * p \leq 0.001$.

and DC Protein Assay kit (Bio-Rad). A significant increase $(p=0.001)$ of urinary albumin was observed $12 \mathrm{~h}$ after LPS treatment, with a maximum increase at $24 \mathrm{~h}(215.87 \pm 1.41$ $\mu \mathrm{g} / \mathrm{ml})$ compared to the control $(15.53 \pm 5.0 \mu \mathrm{g} / \mathrm{ml}$ ) (Figure 1A). The concentration of total urinary protein was observed to peak at $36 \mathrm{~h}(26.02 \pm 2.43 \mathrm{mg} / \mathrm{ml})$ and was significantly higher compared to the control $(p=0.01)$ as shown in Figure 1 . The renal damage induced by LPS was analyzed by histology. At $24 \mathrm{~h}$ after treatment, focal glomerulonephritis was observed in kidney tissue, with the greatest damage being found at $36 \mathrm{~h}$, increasing the size of the glomerulus, with mesangial cell proliferation. At $48 \mathrm{~h}$ after, a gradual recovery of the glomerulus it was observed until $72 \mathrm{~h}$, as shown in Figure 1C.

Production of the pro-inflammatory cytokines TNF $\alpha$ and ILI $\beta$ in serum from LPS-treated mice. To confirm kidney damage was induced by LPS, pro-inflammatory cytokines levels were measured by enzyme-linked immunosorbent assay. An increase of TNF $\alpha$ and IL1 $\beta$ was observed after $12 \mathrm{~h}(3.6 \pm 0.9 \mathrm{ng} / \mathrm{ml}$, $11.9 \pm 5 \mathrm{ng} / \mathrm{ml})$ and up to $36 \mathrm{~h}(4.44 \pm 0.1 \mathrm{ng} / \mathrm{ml}, 18 \pm 0.9 \mathrm{ng} / \mathrm{ml}$ respectively) of treatment with LPS, beginning to decline thereafter (Figure 2A and B). IL6 expression was increased at
$12 \mathrm{~h}(49.5 \mathrm{ng} / \mathrm{ml})$ and $36 \mathrm{~h}(23.5 \mathrm{ng} / \mathrm{ml})$ post treatment, being significantly higher than the control (Figure 2C).

WT1 gene expression in kidney tissue from LPS-treated mice. In order to answer our central question of whether WT1 was modulated by the inflammatory process, and this had renal affects, the total expression of WT1 gene was determined in renal samples from mice with systemic inflammation at different times in the course of inflammation. WT1 mRNA was lower at all times analyzed with respect to the control, with the lowest relative expression at $36 \mathrm{~h}$ and the highest at $12 \mathrm{~h}$ after induction of systemic inflammation as shown in Figure 3A. In addition, it was determined whether the treatment with LPS induced modification of the expression of the isoform's exon 5 (17 AA \pm ) and $\mathrm{KTS} \pm$ of $W T 1$ by PCR. The data showed that there was no deregulation of the expression of these isoforms as the same behavior was observed as the control group without treatment throughout the systemic inflammatory process induced by LPS (Figure 3B). WT1 protein was shown by western blotting to decrease throughout the inflammatory process, with a slight recovery at $36 \mathrm{~h}$ after treatment, however, the amount of WT1 was less than that of the untreated control (Figure 3C and D). 
A

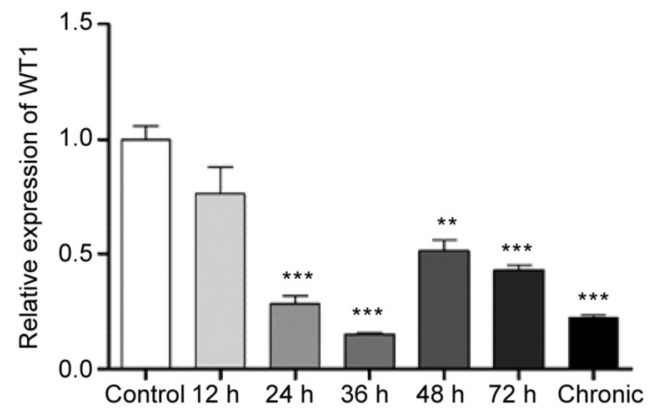

B

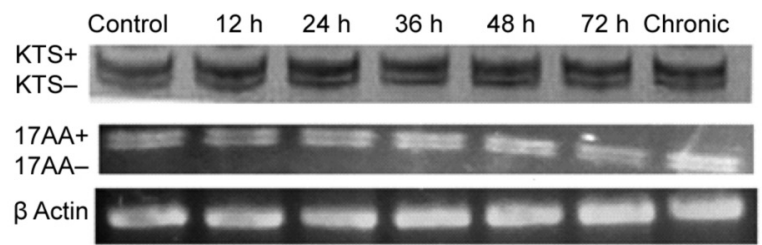

C

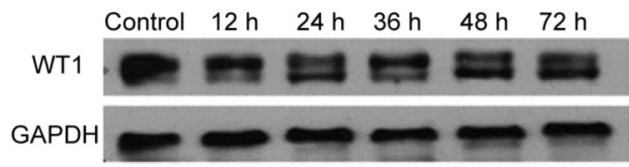

D

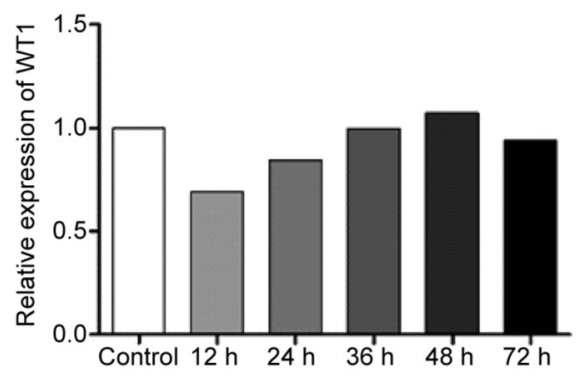

Figure 3. Effect of lipopolysaccharide (LPS) on Wilms' tumor 1 (WT1) gene expression in kidney tissue from mice with systemic inflammation. A: Relative expression of WT1 mRNA. B: Relative expression of isoforms KTS \pm and 17/AA \pm of WT1. C: Levels of WT1 protein by immunoblotting after LPS treatment and D: Density of immunoblotting for WT1. Significantly different at: **p $\leq 0.01$ and $* * * p \leq 0.001$.

Phosphorylation and localization of WT1 in kidney biopsies of LPS-treated mice. An important event in the post-translational modulation of WT1 protein is the phosphorylation of amino acid 393, which induces the displacement of the protein to the cytoplasm. Phosphorylation and localization of WT1 in kidney samples from mice treated with LPS were determined. Phosphorylation of WT1 was analyzed by histochemistry, indicating the presence of phosphorylated WT1 in the cytoplasm of the cells in sections of renal tissue starting $12 \mathrm{~h}$ after the induction of systemic inflammation and being maintained until $72 \mathrm{~h}$. WT1 was phosphorylated at amino acid 393 and 363 as shown in Figure 4A. The location of the WT1 protein was analyzed by immunofluorescence. The location of WT1 in podocytes in kidney samples from LPS-treated mice was mainly cytoplasmic, whereas in the podocytes from the control samples, the location was nuclear (Figure 4B).

Modulation of the expression of WT1 and nephrin in kidneys from LPS-treated mice. WT1 location in the cell influences its biological activity. It has been reported that cytoplasmic WT1 does not exert transcriptional activity; for this reason, the expression of WT1 and nephrin mRNA was analyzed by PCR in kidney samples from mice treated with LPS (Figure 5A). PCR indicated a decrease in nephrin mRNA from 24 to $48 \mathrm{~h}$, with an increase at $72 \mathrm{~h}$ (Figure 5B), while the expression of WT1 mRNA increased at $12 \mathrm{~h}$ and thereafter declined during the critical hours of inflammation and kidney damage (24 and $36 \mathrm{~h}$ ) and (Figure 5B).
Kidney explants treated with TNF $\alpha$ and ILI $\beta$ modulate expression of WT1 and nephrin. To determine if the cytokines modulate the expression of WT1, renal explants were cultured and treated with the cytokines TNF $\alpha$ and IL1 $\beta$ for 6,12 , and $24 \mathrm{~h}$ to analyze the expression of WT1 and nephrin by PCR. Nephrin mRNA expression decreased and WT1 mRNA expression increased at $24 \mathrm{~h}$ in renal explants treated with TNFa and IL1b (Figure 6).

Localization of WT1 in renal explants by immunofluorescence. To determine whether TNF $\alpha$ and IL1 $\beta$ were responsible for the change in localization of the WT1 protein, mouse kidney explants were treated with TNF $\alpha$ and IL1 $\beta$ and LPS for $24 \mathrm{~h}$. In explants treated with IL1b and LPS, a nucleus/cytoplasmic localization of WT1 protein was apparent, and in the explants treated with TNFa, cytoplasmic localization of WT1 protein was observed; meanwhile in untreated controls, a mainly nuclear localization of WT1 was observed (Figure 7).

\section{Discussion}

WT1 plays an important role in the genitourinary development and maintenance of podocytes throughout life (9). WT1 mutations are associated with a broad spectrum of clinical phenotypes $(11,26,27)$, immunosuppressive treatment and renal alterations indicate that immunity and inflammation play an important role in the pathogenesis of diabetic kidney disease (28) and nephrotic syndrome (29). The steroid-resistant 
A Control $12 \mathrm{~h}$

$24 \mathrm{~h}$ $36 \mathrm{~h}$ $48 \mathrm{~h}$ p-WT1 (393)
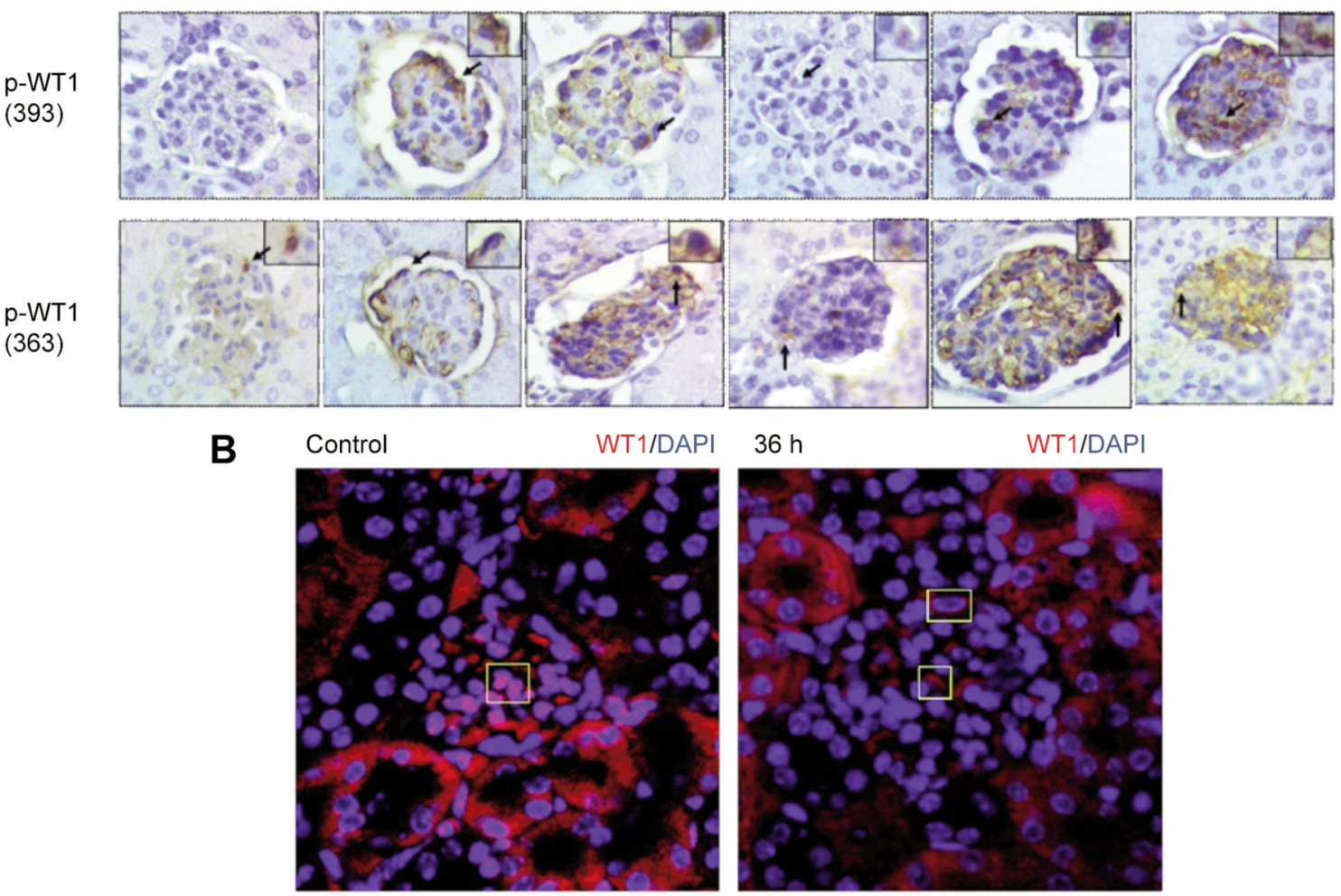

Figure 4. Phosphorylation and localization of Wilms' tumor 1 (WT1) in kidney samples from lipopolysaccharide-treated mice. A: Immunohistochemical staining for phosphorylated (p)-WT1 showing an increase in phosphorylated at serine 393 and 363 starting 12 h after LPS administration (magnification 100x on light microscope). B: Localization of WT1 by immunofluorescence in kidney; examples showing minor nuclear localization of WT1 (squares) 36 h after of the administration of lipopolysaccharide (magnification 40x on confocal microscope). DAPI: 4,6-Diamidino-2-phenylindole.

nephrotic syndrome is due to the loss of WT1 function during the development and maintenance of podocytes $(7,11)$ and corticosteroids are the mainstay of treatment (29) and have reduced the death rate to around $3 \%$ (30).

There is increasing evidence that immunity and low-grade inflammation are an important component of the pathogenesis of diabetic kidney disease. Inflammation has become a center of interest in kidney injury, along with increased levels of inflammatory cytokines, such as IL1 $\beta$, TNF $\alpha$ and monocyte chemoattractant protein-1 both in patients and in experimental models (28). The objective of this study was to analyze how the inflammatory process modulates the expression and posttranslational activity of WT1 and how it affects its functionality as a transcription factor in podocytes in mice treated with LPS. For this work, we established the murine model of transient sepsis with LPS (16). Podocyte injury is a key event for progressive renal failure, in this work, renal damage was analyzed by means of histology, proteinuria, and increase in blood of pro-inflammatory cytokines. At $36 \mathrm{~h}$, the greatest damage was seen in podocytes with a gradual regression at 72 h, as observed by Kato et al. (16). As mentioned above, mutation (31) or reduced expression of WT1 (9) lead to the clinical and pathological characteristics associated with nephropathy. For this reason, we analyzed the expression of WT1 in kidney damage, observing a decrease in the expression of WT1 mRNA and protein in renal tissue; the decrease in the expression of WT1 in biopsies of patient with nephrotic syndrome and in different mouse models of inflammatory processes has already been reported $(15,32,33)$.

The transcriptional regulation of the WT1 gene leads to four isoforms originating from alternative splicing of exon 5 whereby the protein contains or lacks 17 amino acids, and of exon 9 that results in the insertion or absence of three amino acids KTS is the predominant isoform in the transcriptional regulation in the kidney (34), the alteration of the normal ratio of the splicing isoforms WT1 KTS- and WT1 KTS+ seems to be sufficient to explain the developmental anomalies in Frasier syndrome, Denys-Drash syndrome and intrauterine growth restriction $(35,36)$. In this work, we analyzed whether LPS affects the expression pattern of the KTS \pm isoforms and whether 
A

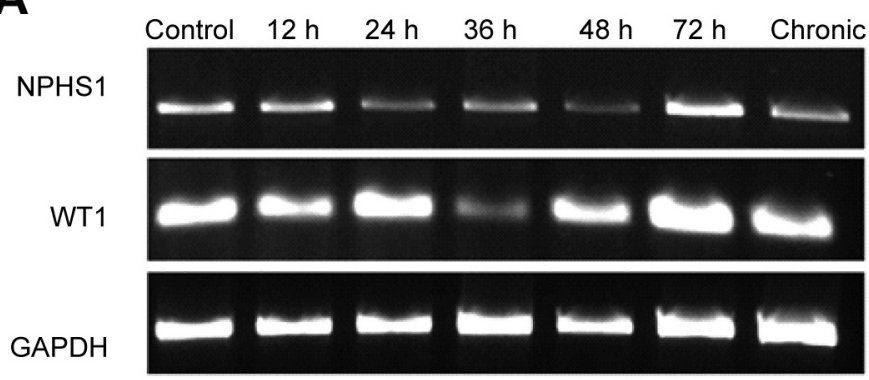

B

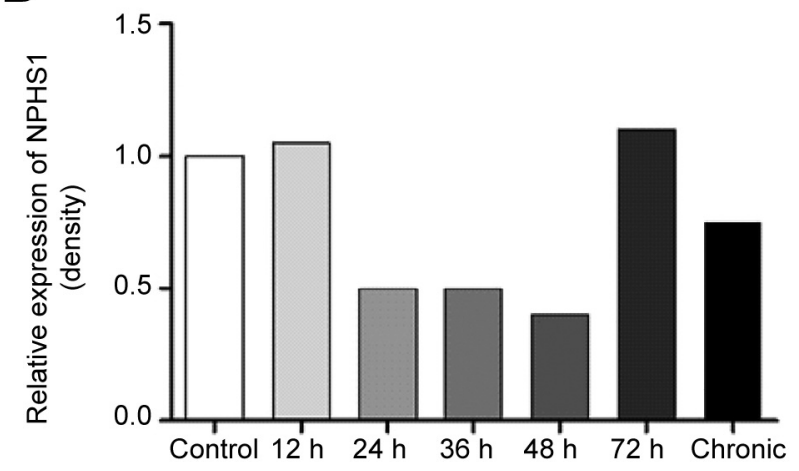

C

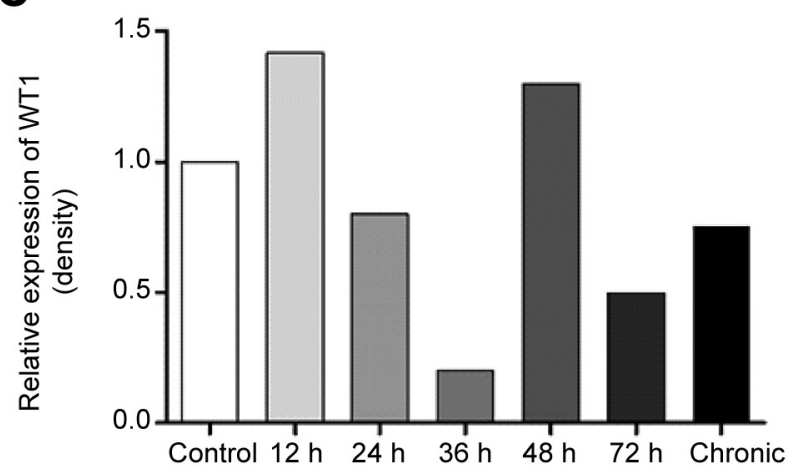

Figure 5. Analysis of nephrin (NPHS1) and Wilms' tumor 1 (WT1) mRNA expression. A: In the analysis of mRNA expression, NPHS1 and WT1 decreased at 24, 36 and $48 \mathrm{~h}$ after the induction of systemic inflammation using lipopolysaccharide. B: Quantification of the bands shown in A by densitometry and normalized by expression to glyceraldehyde 3-phosphate dehydrogenase.

A

$\frac{\text { Control }}{0 \mathrm{~h} \quad 6 \mathrm{~h} \quad 12 \mathrm{~h} \quad 24 \mathrm{~h}} \frac{\text { TNFa }}{6 \mathrm{~h} \quad 12 \mathrm{~h} \quad 24 \mathrm{~h}} \quad \frac{\text { IL1 }}{6 \mathrm{~h} \quad 12 \mathrm{~h} \quad 24 \mathrm{~h}}$

WT1

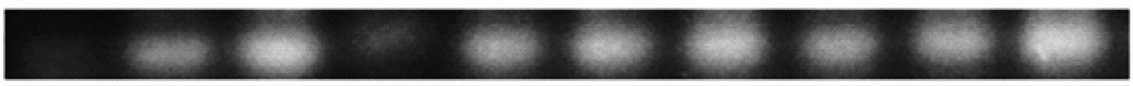

NPHS1

GAPDH

B

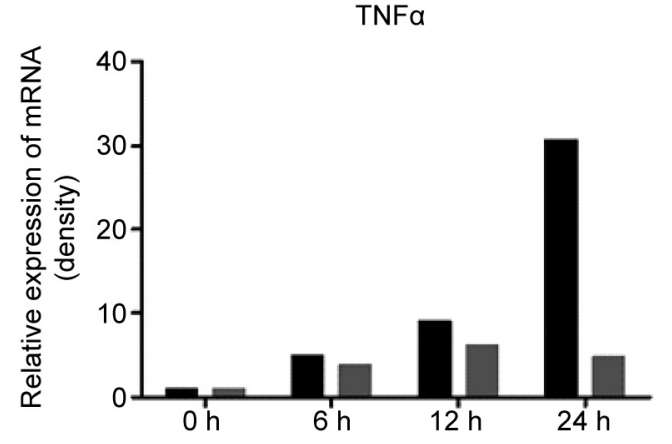

C

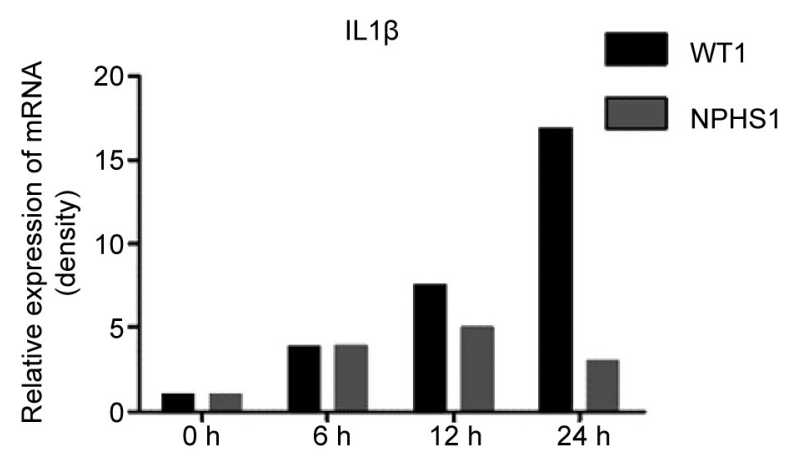

Figure 6. Analysis of the expression of nephrin (NPHS1) and Wilms' tumor 1 (WT1) mRNA in renal explants. A: mRNA expression levels of NPHS1 and WT1 at different times in renal explants exposed to $10 \mathrm{ng} / \mathrm{ml}$ of tumor necrosis factor alpha (TNF $\alpha$ ), and $20 \mathrm{ng} / \mathrm{ml}$ of interleukin $1 \beta$ (IL1 $\beta$ ). B: Relative expression obtained using densitometric analysis of the signal product. The bands were quantified by normalization to glyceraldehyde 3-phosphate dehydrogenase. 

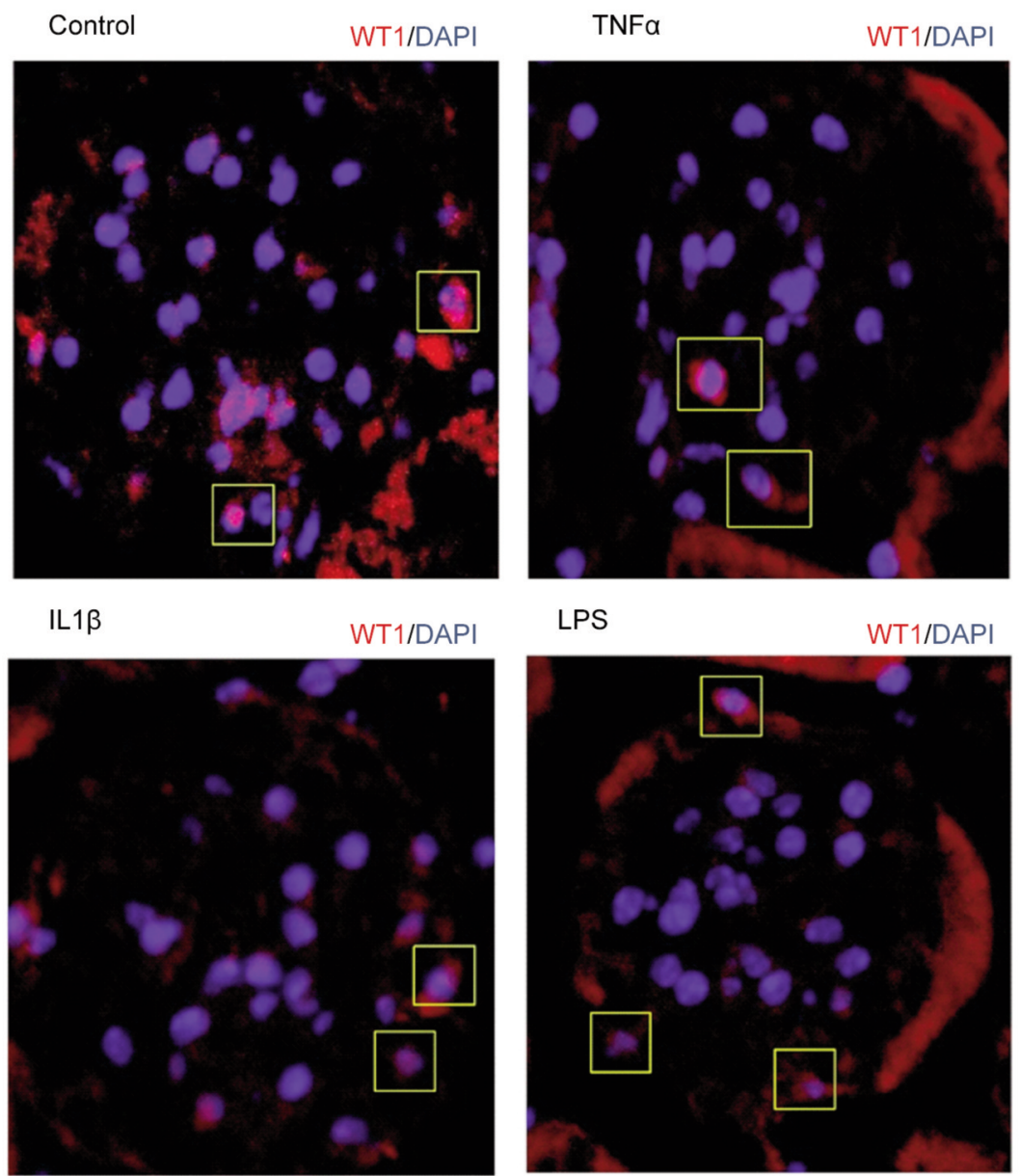

Figure 7. Localization of the Wilms' tumor 1 (WT1) protein by immunofluorescence using Red TX (WT1) and 4',6-diamidino-2-phenylindole (DAPI) (nucleus) in podocytes from kidney explants treated with $10 \mathrm{ng} / \mathrm{ml}$ of tumor necrosis factor alpha (TNF $\alpha), 20 \mathrm{ng} / \mathrm{ml}$ of interleukin $1 \beta$ (IL1 $\beta$ ), and lipopolysaccharide (LPS). Reduced nuclear localization of WTas shown in the explants treated with TNFa compared to the nuclear/cytoplasmic localization of WT1 under ILI $\beta$ and LPS treatments. Magnification, 40x.

this is correlated with the pathology of the disease. However, no differences were found in the expression patterns. MendezCastro et al. observed that the imbalance in the isoforms were already present at the time of birth in a murine model (35).

In the inflammatory process, it has been reported that WT1 is overexpressed through nuclear factor kappa B, a protein that modulates inflammation-associated genes (37). However, Okabe et al. reported that in podocytes injured by immunotoxin, Maf bZIP transcription factor F (MafF) and early growth response-1 were up-regulated and these may promote deterioration of podocytes by antagonizing MafB and WT1. (33). Phosphorylation is one of the main post-translational mechanisms by which the activity of transcription factors is regulated (33). WT1 protein is phosphorylated at sites such as Ser-365 and Ser-393, by protein kinase A (PKA) and protein kinase $\mathrm{C}$ abolished the DNA-binding activity of WT1 in vitro (19). In our work, at $12 \mathrm{~h}$ after the treatment of the mice with
LPS, renal samples of biopsies were positive for WT1 phosphorylation at Ser-365 and Ser-393, and phosphorylated WT1 protein was found at the same time that protein in urine and cytokines in serum increased. WT1 zinc fingers contain two functionally independent targeting signals required for nuclear localization of the protein (38). This expression pattern is altered upon PKA activation, phosphorylating WT1 and abolished the WT1 DNA-binding activity and resulting in the cytoplasmic retention of WT1 (18). In the A549 lung cancer cell line, TNF $\alpha$ was observed to induce translocation of WT1 from the nucleus to the cytosol through PKA and increase the expression of protein matrix metalloproteinase-9, a protein repressed by WT1 (7). In this work a decrease in the expression of WT1 and nephrin was observed in the kidneys of mice treated with LPS. In contrast, in renal explants treated with TNF $\alpha$ and IL $1 \beta$ we observed an increase in the expression of WT1 and nephrin, indicating that the influence of pro-inflammatory cytokines and 
the cellular microenvironment modulate the expression of WT1 and this in turn leads to the expression of nephrin.

Another research group reported the reduction of nephrin expression and its correlation with cytoplasmic localization of WT1 in a sepsis model (16). Therefore, our results indicate that the immune system plays an important role in the modulation of WT1 expression and this, in turn, in the clinical manifestation of kidney disease.

\section{Conclusion}

In this work, we observed that the inflammatory process through TNF $\alpha$ and IL $\beta$ modulates WT1 expression and posttranslational regulation of WT1 protein by interference with nuclear translocation. This led to reduced nephrin expression, inducing renal damage with proteinuria and morphological alterations in kidney glomeruli in a model of systemic inflammation induced with LPS in mice.

\section{Conflicts of Interest}

The Authors declare that they have no conflicts of interest.

\section{Authors' Contributions}

Formal analysis: Pablo Zapata-Benavides, Felipe de Jesús Torres del Muro and Edgar Mendoza-Gamboa. Funding acquisition: Cristina Rodríguez-Padilla. Investigation: Mariela Arellano-Rodríguez, Pablo Zapata-Benavides and Santiago Saavedra-Alonso. Methodology: Norma Cesilia Arellano-Rodríguez, Moisés Armides Franco-Molina, Juan Manuel Izaguirre-Álvarez and Adolfo Soto-Domínguez. Article writing and final approval of article: All Authors.

\section{Acknowledgements}

The present study was supported by research grant CB-182231 from Consejo Nacional de Ciencia y Tecnología (CONACYT).

\section{References}

1 Yang L, Han Y, Suarez Saiz F and Minden MD: A tumor suppressor and oncogene: the WT1 story. Leukemia 21(5): 868876, 2007. PMID: 17361230. DOI: 10.1038/sj.leu.2404624

2 Englert C, Vidal M, Maheswaran S, Ge Y, Ezzell RM, Isselbacher KJ and Haber DA: Truncated WT1 mutants alter the subnuclear localization of the wild-type protein. Proc Natl Acad Sci U.S.A. 92(26): 11960-11964, 1995. PMID: 8618823. DOI: 10.1073/pnas.92.26.11960

3 Larsson SH, Charlieu JP, Miyagawa K, Engelkamp D, Rassoulzadegan M, Ross A, Cuzin F, van Heyningen V and Hastie ND: Subnuclear localization of WT1 in splicing or transcription factor domains is regulated by alternative splicing. Cell 81(3): 391401, 1995. PMID: 7736591. DOI: 10.1016/0092-8674(95)90392-5

4 Fanni D, Fanos V, Monga G, Gerosa C, Locci A, Nemolato S, Van Eyken P and Faa G: Expression of WT1 during normal human kidney development. J Matern Fetal Neonatal Med 24 Suppl 2: 4447, 2011. PMID: 21888469. DOI: 10.3109/14767058.2011.606619
5 Mishra OP, Singh AK, Abhinay A, Narayan G, Prasad R and Batra VV: WT1 mutations in steroid-resistant idiopathic nephrotic syndrome. Saudi J Kidney Dis Transpl 27(2): 417-418, 2016. PMID: 26997404. DOI: 10.4103/1319-2442.178590

6 Palmer RE, Kotsianti A, Cadman B, Boyd T, Gerald W and Haber DA: WT1 regulates the expression of the major glomerular podocyte membrane protein Podocalyxin. Curr Biol 11(22): 1805-1809, 2001. PMID: 11719225. DOI: 10.1016/ s0960-9822(01)00560-7

7 Lipska BS, Ranchin B, Iatropoulos P, Gellermann J, Melk A, Ozaltin F, Caridi G, Seeman T, Tory K, Jankauskiene A, Zurowska A, Szczepanska M, Wasilewska A, Harambat J, Trautmann A, Peco-Antic A, Borzecka H, Moczulska A, Saeed B, Bogdanovic R, Kalyoncu M, Simkova E, Erdogan O, Vrljicak K, Teixeira A, Azocar M, Schaefer F and PodoNet Consortium: Genotypephenotype associations in WT1 glomerulopathy. Kidney Int 85(5): 1169-1178, 2014. PMID: 24402088. DOI: 10.1038/ki.2013.519

8 Dong L, Pietsch S and Englert C: Towards an understanding of kidney diseases associated with WT1 mutations. Kidney Int 88(4): 684-690, 2015. PMID: 26154924. DOI: 10.1038/ki.2015.198

9 Guo JK, Menke AL, Gubler MC, Clarke AR, Harrison D, Hammes A, Hastie ND and Schedl A: WT1 is a key regulator of podocyte function: reduced expression levels cause crescentic glomerulonephritis and mesangial sclerosis. Hum Mol Genet 11(6): 651-659, 2002. PMID: 11912180. DOI: 10.1093/hmg/11.6.651

10 Seo JW, Kim YG, Lee SH, Lee A, Kim DJ, Jeong KH, Lee KH, Hwang SJ, Woo JS, Lim SJ, Kim W and Moon JY: Mycophenolate mofetil ameliorates diabetic nephropathy in $\mathrm{db} / \mathrm{db}$ mice. Biomed Res Int 2015: 301627, 2015. PMID: 26345532. DOI: $10.1155 / 2015 / 301627$

11 Chernin G, Vega-Warner V, Schoeb DS, Heeringa SF, Ovunc B, Saisawat P, Cleper R, Ozaltin F, Hildebrandt F and Members of the GPN Study Group: Genotype/phenotype correlation in nephrotic syndrome caused by WT1 mutations. Clin J Am Soc Nephrol 5(9): 1655-1662, 2010. PMID: 20595692. DOI: 10.2215/CJN.09351209

12 Siji A, Pardeshi VC, Ravindran S, Vasudevan A and Vasudevan A: Screening of WT1 mutations in exon 8 and 9 in children with steroid resistant nephrotic syndrome from a single centre and establishment of a rapid screening assay using high-resolution melting analysis in a clinical setting. BMC Med Genet 18(1): 3, 2017. PMID: 28068926. DOI: 10.1186/s12881-016-0362-7

13 Wang F, Zhang Y, Mao J, Yu Z, Yi Z, Yu L, Sun J, Wei X, Ding F, Zhang H, Xiao H, Yao Y, Tan W, Lovric S, Ding J and Hildebrandt F: Spectrum of mutations in Chinese children with steroid-resistant nephrotic syndrome. Pediatr Nephrol 32(7): 11811192, 2017. PMID: 28204945. DOI: 10.1007/s00467-017-3590-y

14 Ruf RG, Schultheiss M, Lichtenberger A, Karle SM, Zalewski I, Mucha B, Everding AS, Neuhaus T, Patzer L, Plank C, Haas JP, Ozaltin F, Imm A, Fuchshuber A, Bakkaloglu A, Hildebrandt F and APN Study Group: Prevalence of WT1 mutations in a large cohort of patients with steroid-resistant and steroidsensitive nephrotic syndrome. Kidney Int 66(2): 564-570, 2004. PMID: 15253707. DOI: 10.1111/j.1523-1755.2004.00775.x

15 Zapata-Benavides P, Arellano-Rodríguez M, Bollain-Y-Goytia JJ, Franco-Molina MA, Rangel-Ochoa GA, Avalos-Díaz E, Herrera-Esparza $\mathrm{R}$ and Rodríguez-Padilla $\mathrm{C}$ : Cytoplasmic localization of WT1 and decrease of miRNA-16-1 in nephrotic syndrome. Biomed Res Int 2017: 9531074, 2017. PMID: 28299339. DOI: $10.1155 / 2017 / 9531074$ 
16 Kato T, Mizuno S and Kamimoto M: The decreases of nephrin and nuclear WT1 in podocytes may cause albuminuria during the experimental sepsis in mice. Biomed Res 31(6): 363-369, 2010. PMID: 21187647. DOI: 10.2220/biomedres.31.363

17 Marcet-Palacios M, Ulanova M, Duta F, Puttagunta L, Munoz S, Gibbings D, Radomski M, Cameron L, Mayers I and Befus AD: The transcription factor Wilms tumor 1 regulates matrix metalloproteinase-9 through a nitric oxide-mediated pathway. J Immunol 179(1): 256-265, 2007. PMID: 17579045. DOI: 10.4049/jimmunol.179.1.256

18 Ye Y, Raychaudhuri B, Gurney A, Campbell CE and Williams BR: Regulation of WT1 by phosphorylation: inhibition of DNA binding, alteration of transcriptional activity and cellular translocation. EMBO J 15(20): 5606-5615, 1996. PMID: 8896454.

19 Sakamoto Y, Yoshida M, Semba K and Hunter T: Inhibition of the DNA-binding and transcriptional repression activity of the Wilms' tumor gene product, WT1, by cAMP-dependent protein kinase-mediated phosphorylation of Ser-365 and Ser-393 in the zinc finger domain. Oncogene 15(17): 2001-2012, 1997. PMID: 9366517. DOI: $10.1038 /$ sj.onc. 1201391

20 Nouri M, Ahmadi A, Etezadi F, Barzegar E and Mojtahedzadeh M: Comparison of the effects of subcutaneous versus continuous infusion of heparin on key inflammatory parameters following sepsis. Anesth Pain Med 6(2): e33780, 2016. PMID: 27252904. DOI: $10.5812 /$ aapm. 33780

21 Chen H, Zhu J, Liu Y, Dong Z, Liu H, Liu Y, Zhou X, Liu F and Chen G: Lipopolysaccharide induces chronic kidney injury and fibrosis through activation of mTOR signaling in macrophages. Am J Nephrol 42(4): 305-317, 2015. PMID: 26517816. DOI: $10.1159 / 000441506$

22 Trostel J and Garcia GE: Endogenous inhibitors of kidney inflammation. J Nephrol Res 1(2): 61-68, 2015. PMID: 26779569.

23 Pfaffl MW: A new mathematical model for relative quantification in real-time RT-PCR. Nucleic Acids Res 29(9): e45, 2001. PMID: 11328886. DOI: 10.1093/nar/29.9.e45

24 Oji Y, Miyoshi S, Maeda H, Hayashi S, Tamaki H, Nakatsuka S, Yao M, Takahashi E, Nakano Y, Hirabayashi H, Shintani Y, Oka Y, Tsuboi A, Hosen N, Asada M, Fujioka T, Murakami M, Kanato K, Motomura M, Kim EH, Kawakami M, Ikegame K, Ogawa H, Aozasa K, Kawase I and Sugiyama H: Overexpression of the Wilms' tumor gene WT1 in de novo lung cancers. Int J Cancer 100(3): 297-303, 2002. PMID: 12115544. DOI: 10.1002/ijc.10476

25 Laux DE, Curran EM, Welshons WV, Lubahn DB and Huang TH: Hypermethylation of the Wilms' tumor suppressor gene $\mathrm{CpG}$ island in human breast carcinomas. Breast Cancer Res Treat 56(1): 3543, 1999. PMID: 10517341. DOI: 10.1023/a:1006222803788

26 Ho PA, Zeng R, Alonzo TA, Gerbing RB, Miller KL, Pollard JA, Stirewalt DL, Heerema NA, Raimondi SC, Hirsch B, Franklin JL, Lange B and Meshinchi S: Prevalence and prognostic implications of WT1 mutations in pediatric acute myeloid leukemia (AML): a report from the Children's Oncology Group. Blood 116(5): 702-710, 2010. PMID: 20413658. DOI: 10.1182/blood-2010-02-268953

27 Coppes MJ, Liefers GJ, Higuchi M, Zinn AB, Balfe JW and Williams BR: Inherited WT1 mutation in Denys-Drash syndrome. Cancer Res 52(21): 6125-6128, 1992. PMID: 1327525.

28 Yu G, Liu Q, Dong X, Tang K, Li B, Liu C, Zhang W, Wang Y and Jin Y: Inhibition of inflammation using diacerein markedly improved renal function in endotoxemic acute kidney injured mice. Cell Mol Biol Lett 23: 38, 2018. PMID: 30140293. DOI: 10.1186/s11658-018-0107-z
29 Larkins N, Kim S, Craig J and Hodson E: Steroid-sensitive nephrotic syndrome: an evidence-based update of immunosuppressive treatment in children. Arch Dis Child 101(4): 404408, 2016. PMID: 26289063. DOI: 10.1136/archdischild-2015308924

30 Hahn D, Hodson EM, Willis NS and Craig JC: Corticosteroid therapy for nephrotic syndrome in children. Cochrane Database Syst Rev (3): CD001533, 2015. PMID: 25785660. DOI: 10.1002/14651858.CD001533.pub5

31 Sun LZ, Wang HY, Li M, Lin HR, Wu JL, Tang W, Li YJ, Yue ZH, Liu T, Chen HM and Hu MY: [Clinical and pathological features and mutational types of WT1 mutation-associated nephropathy]. Zhonghua Er Ke Za Zhi 56(10): 769-774, 2018. PMID: 30293282. DOI: 10.3760/cma.j.issn.0578-1310.2018. 10.010

32 Fujita Y, Tominaga T, Abe H, Kangawa Y, Fukushima N, Ueda O, Jishage KI, Kishi S, Murakami T, Saga Y, Kanwar YS, Nagai $\mathrm{K}$ and Doi T: An adjustment in BMP4 function represents a treatment for diabetic nephropathy and podocyte injury. Sci Rep 8(1): 13011, 2018. PMID: 30158674. DOI: 10.1038/s41598-01831464-9

33 Okabe M, Motojima M, Miyazaki Y, Pastan I, Yokoo T and Matsusaka T: Global polysome analysis of normal and injured podocytes. Am J Physiol Renal Physiol 316(2): F241-F252, 2019. PMID: 30379099. DOI: 10.1152/ajprenal.00115.2018

34 Wells J, Rivera MN, Kim WJ, Starbuck K and Haber DA: The predominant WT1 isoform (+KTS) encodes a DNA-binding protein targeting the planar cell polarity gene Scribble in renal podocytes. Mol Cancer Res 8(7): 975-985, 2010. PMID: 20571064. DOI: $10.1158 / 1541-7786 . M C R-10-0033$

35 Menendez-Castro C, Hilgers KF, Amann K, Daniel C, Cordasic N, Wachtveitl R, Fahlbusch F, Plank C, Dötsch J, Rascher W and Hartner A: Intrauterine growth restriction leads to a dysregulation of Wilms' tumour supressor gene 1 (WT1) and to early podocyte alterations. Nephrol Dial Transplant 28(6): 14071417, 2013. PMID: 23229934. DOI: $10.1093 /$ ndt/gfs517

36 Lahiri D, Dutton JR, Duarte A, Moorwood K, Graham CF and Ward A: Nephropathy and defective spermatogenesis in mice transgenic for a single isoform of the Wilms' tumour suppressor protein, WT1-KTS, together with one disrupted Wt1 allele. Mol Reprod Dev 74(3): 300-311, 2007. PMID: 16967512. DOI: 10.1002/mrd.20491

37 Dehbi M, Hiscott J and Pelletier J: Activation of the wt1 Wilms' tumor suppressor gene by NF-kappaB. Oncogene 16(16): 20332039, 1998. PMID: 9572484. DOI: 10.1038/sj.onc.1201747

38 Bruening W, Moffett P, Chia S, Heinrich G and Pelletier J: Identification of nuclear localization signals within the zinc fingers of the WT1 tumor suppressor gene product. FEBS Lett 393(1): 41-47, 1996. PMID: 8804420. DOI: 10.1016/00145793(96)00853-8
Received July 4, 2021

Revised August 15, 2021 Accepted September 9, 2021 